\title{
INVESTIGATION OF METAL TREATMENT PROCESS
}

\author{
J. JANUTĖNIENE, G. PRIDOTKAS and R. DIDŽIOKAS \\ Klaipèda University \\ H. Manto 84, Klaipèda, 5800 Lithuania \\ E-mail: mechanik@jtf.ku.lt
}

Received October 1, 2001; revised December 172001

\begin{abstract}
Differential equations of self-excited oscillations, arising in metal cutting process and metal drilling process, are presented in this paper. The causes of these oscillations are delaying forces, arising in metal treatment processes. The linear analysis of differential equations of metal cutting process is performed and an area of asymptotically stability is chosen. The non-linear analysis is performed by the theory of bifurcation. Solution of this differential equation is compared with results of numerical experiment. Differential equations of dynamic of metal drilling process are presented.
\end{abstract}

\section{INTRODUCTION}

In the practice of metal treatment by cutting it is frequently necessary to deal with oscillations of the cutting tool, taking into account details and units of the machine tool. These oscillations are an obstacle on the way to increase the productivity and quality of details treatment on a metal-cutting machines. The most difficult is to eliminate and at the same time to investigate selfexcited oscillations. The frequency of self-excited oscillations can reach up to $5000 \mathrm{~Hz}$ and higher. The stability of the process of chip formation is one of the main conditions, which should be satisfies by metal-cutting machine.

It is impossible to find the condition, when the self-excited oscillations don't arise. Linear analysis of differentials equations of self-excited oscillations is performed in [6]. An area of asymptotically stability is determined. Nonlinear analysis of differential equations is presented in [7]. Results of computational experiment and comparison to the solution of differential equation of metal cutting process are presented in this article.

Self-excited oscillation in metal drilling process decrease the accuracy and 
quality of processing detail, decline the productivity of the machine tool, decrease the resistance of the tool, and break of the drill at deep drilling. We suppose that cause of oscillation in metal drilling process is the same as in a metal cutting process.

\section{DYNAMICS OF CUTTING PROCESS}

For the development of a theory of self excited oscillations at cutting it is necessary to use conformity with the law of the accompanying deformations of treated metal $[3 ; 4]$. Particularity of the process of cutting is related to plastic properties of metal. The cutting force, acting to lathe tool, is delay in relation to coordinates of lathe tool. The self-excited oscillations at metal cutting are a result of delay of forces, which shake the system.

The reason of delay of forces at cutting of metal is the features of deformation process [3]. The edge $a$ of lathe tool $A$ (Fig.1) does not constantly participates in deformation of the main chip, but only incises the layer of material and thus starts the deformation process. At small oscillation of the system in direction $x$ the oscillation of thickness of the chip and of the force $P$ periodically detain. The cutting force dependence on time [8].

An equation is given by

$$
\Delta P(t)=B \Delta x\left(t-\tau_{p}\right)
$$

The friction force delay is related to cutting force:

$$
\Delta Q(t)=f \Delta P\left(t-\tau_{Q}\right)
$$

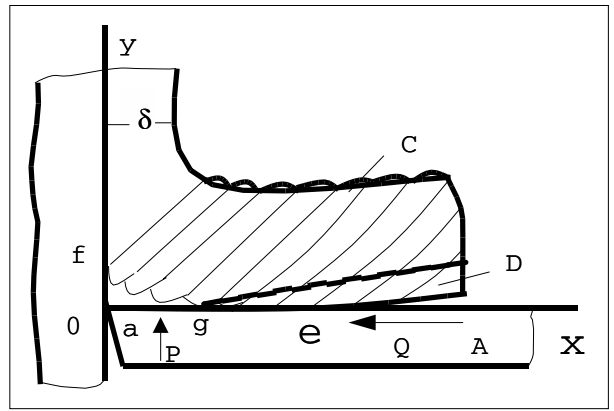

Figure 1. The process of the chip formation. 
Equations of the small oscillation of dynamic systems are given by

$$
\begin{aligned}
& \ddot{x}(t)+\frac{b_{x}}{m_{x}} x(t)+\omega_{x}^{2} x(t)=-\frac{f B}{m_{x}} x\left(t-\tau_{p}-\tau_{Q}\right), \\
& \ddot{y}(t)+\frac{b_{y}}{m_{y}} \dot{y}(t)+\omega_{y}^{2} y(t)=-\frac{B}{m_{y}} x\left(t-\tau_{p}\right),
\end{aligned}
$$

where $\omega_{x}^{2}=c_{x} / m_{x} ; m_{x}$ and $m_{y}$ are masses, $c_{x}$ and $c_{y}$ - coefficients of elasticity.

The time of delay depends on the solution

$$
\tau_{p}=\frac{l_{p}}{v_{s}+\dot{y}}, \quad \tau_{Q}=\frac{l_{Q}}{v_{s}+\dot{y}+\zeta \dot{x}},
$$

there $l_{p}$ and $l_{Q}$ are the path of delay, $v_{s}$ - cutting speed, $B=k b_{c} \mu \delta^{\mu-1}-$ relative cutting force, $\delta$ - the thickness of the chip, $\mu$ - the power estimating the characteristic of metals and the form of lathe tool, $b_{c}$ - the width of the chip, $k$ - relative pressure.

\subsection{LINEAR ANALYSIS}

After linearizing equation (2.1), we get a linear differential equation

$$
\ddot{x}(t)+\frac{b_{x}}{m_{x}} \dot{x}(t)+\omega_{x}^{2} x(t)+\frac{f B}{m_{x}} x\left(t-\frac{l_{p}+l_{Q}}{v_{s}}\right)=0 .
$$

A characteristic quasi-polynomial of the equation (2.4) is

$$
P(\lambda)=\lambda^{2}+a_{1} \lambda+a_{2}+k_{l} e^{-\lambda h_{Q}},
$$

where $\alpha_{1}=b_{x} / m_{x} ; \alpha_{2}=\omega_{x}^{2} ; k_{1}=(f B) / m_{x} ; h_{Q}=\left(l_{p}+l_{Q}\right) / v_{s}$.

We will look at the distribution of radicals of equation (2.4) in the plane of parameters $k_{1}$ and $\alpha_{2}$ using the method of $D$ - expansion. We get equations of remaining curves of $D$ - expansion in the following parametrical forms:

$$
\left\{\begin{aligned}
k_{1} & =\frac{\alpha_{1} \sigma}{\sin \left(\sigma h_{Q}\right)}, \\
\alpha_{2} & =\sigma-\alpha_{1} \sigma \operatorname{ctg}\left(\sigma h_{Q}\right) .
\end{aligned}\right.
$$

Taking $\sigma \rightarrow 0$, from (2.5) equations we define the return point with the coordinates

$$
\lim _{\sigma \rightarrow 0} \alpha_{2}=-\frac{\alpha_{1}}{h_{Q}} ; \quad \lim _{\sigma \rightarrow 0} k_{1}=\frac{\alpha_{1}}{h_{Q}} .
$$

According to the experimental results $[2 ; 3 ; 4]$ we can calculate the values of the coefficient $\alpha_{1}$ and time of delay $h_{Q}$, when $v_{s}=140 \mathrm{~m} / \mathrm{min}, l_{p}=0.35$ $\mathrm{mm}, l_{Q}=0.32 \mathrm{~mm}, c_{x}=40000 \mathrm{~N} / \mathrm{mm}, m_{x}=4.6410^{-3} \mathrm{Ns}^{2} / \mathrm{mm}, b_{x}=0.0118$ 
$\mathrm{Ns} / \mathrm{mm}$. Putting those values in the equations (2.5) we get $D$ - expansion in the plane parameters $k_{1}$ and $\alpha_{2}$ (Fig. 2).

We must emphasize that in the real cutting process only positive values of parameters $\alpha_{2}$ and $k_{1}$ are important. From the separated areas of $D$ - expansion we are interested in the area $D_{0}$ of asymptotically stability and areas $D_{2}$ which describe self excited oscillations arising during process of cutting.

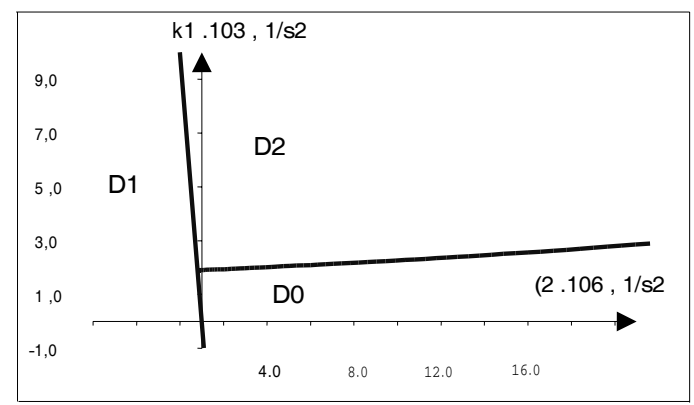

Figure 2. $D$ - expansion in the plane of parameters $k_{1}$ and $\alpha_{2}$.

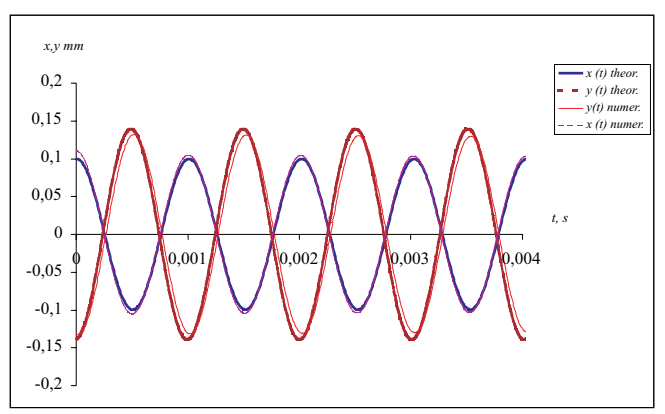

Figure 3. Comparison of functions $y(t) \approx 0.011(0.12 \sin 6237 t-$ $1.336 \cos 6237 t)$ and $x(t) \approx 0,011 \cos 6237 t$ with the results of numerical experiments, when $v_{s}=140 \mathrm{~m} / \mathrm{min}, s=0.6 \mathrm{~mm}, b_{c}=1.4 \mathrm{~mm}$.

Lemma 2.1. The inequality Re $\lambda<0$ is valid for all of the radicals of quasipolynomial in the area $D_{0}$ ( Fig. 2.), i.e. the area. $D_{0}$ is the area of asymptotically stability.

Theorem 2.1. Let's $k_{1}, \alpha_{1} \in D_{0}, h_{Q}>0, \alpha_{2}>0$. Then the state of zero equilibrium of equation (2.3) is asymptotically stable.

Lemma 2.2. Then, $\alpha_{1}>0, \alpha_{2}=0$ and $k_{1}>k_{10}$ quasi-polynomial has a couple of complex joint radicals with the positive real part while real parts of 


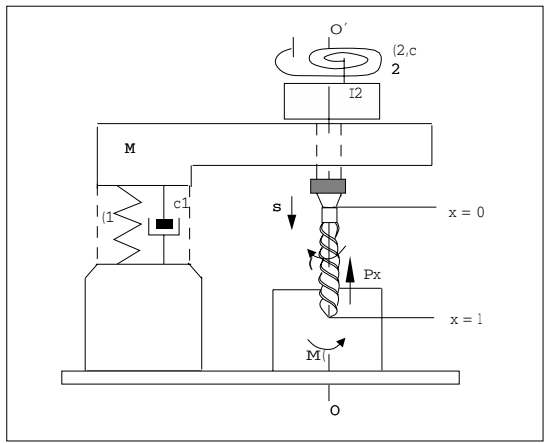

Figure 4. The principle scheme of drilling machine.

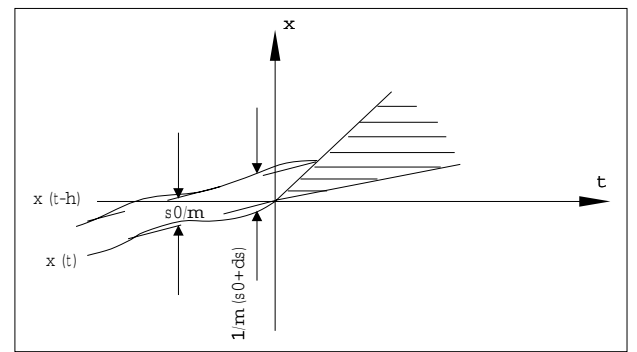

Figure 5. Change of thickness of drill chip during $1 / m$ of a turn of the drill.

other radicals are negative.

The proof of Lemma 2.1 and Lemma 2.2 are presented in [7].

\subsection{NONLINEAR ANALYSIS}

We investigate differential equations by the method of theory of bifurcation. System of differential equations with delay, depending on solution, is given by

$$
\begin{aligned}
& \ddot{x}(t)+\alpha_{1} \dot{x}(t)+\alpha_{2} x(t)+k_{1}(\varepsilon) x\left(t-\tau_{p}-\tau_{Q}\right)=0, \\
& \ddot{y}(t)+\beta_{1} \dot{y}(t)+\beta_{2} x(t)+k_{2} x\left(t-\tau_{p}\right)=0 .
\end{aligned}
$$

Let assume that $k_{1}(\varepsilon)$ depends linearly on a small parameter $\varepsilon$ and

$$
k_{1}(\varepsilon)=k_{10}+\varepsilon
$$

We change time

$$
t=(1+c) \tau
$$


and get a system of differential equations

$$
\left\{\begin{array}{c}
\ddot{x}(\tau)+\alpha_{1} x(\tau)(l+c)+\alpha_{2} x(\tau)\left(l+c^{2}\right) \\
=-\left[(1+c)^{2}\left(k_{1}+\varepsilon\right) x\left(\tau-h_{Q}+W_{1}\right)\right] \\
\ddot{y}(\tau)+\beta_{1} y(\tau)(l+c)+\beta_{2} y(\tau)\left(l+c^{2}\right) \\
=-\left[(1+c)^{2}\left(k_{2}+\varepsilon\right) y\left(\tau-h_{p}+W_{2}\right)\right] .
\end{array}\right.
$$

We will expand all functions in power series by $\xi$

$$
\begin{aligned}
& x(\tau)=\xi \cos \sigma_{0} \tau+\xi^{2} x_{2}(\tau)+\xi^{3} x_{3}(\tau)+\cdots \\
& y(\tau)=\xi y_{1}(\tau)+\xi^{2} y_{2}(\tau)+\xi^{3} y_{3}(\tau)+\cdots \\
& c=\xi^{2} c_{2}+\xi^{4} c_{4}+\cdots \\
& \varepsilon=\xi^{2} b_{2}+\xi^{4} b_{4}+\cdots
\end{aligned}
$$

We will expand the functions $x\left(\tau-h_{Q}+W\right)$ and $y\left(\tau-h_{p}+W_{2}\right)$ by the series of Taylor:

$$
\begin{aligned}
x\left(\tau-h_{Q}\right. & +W)=x\left(\tau-h_{q}\right)+\dot{x}\left(\tau-h_{q}\right) W \\
& +\frac{1}{2} \ddot{x}\left(\tau-h_{q}\right) W^{2}+\cdots \\
y\left(\tau-h_{p}\right. & \left.+W_{2}\right)=y\left(\tau-h_{p}\right)+\dot{y}\left(\tau-h_{p}\right) W_{2} \\
& +\frac{1}{2} \dddot{y}\left(\tau-h_{p}\right) W_{2}^{2}+\cdots
\end{aligned}
$$

After expansion of right and left parts into series in accordance with $\xi$ and after sorting coefficients for the same powers of $\xi$, we get the sequence of linear nonhomogeneous differential equations with the period $2 \pi / \sigma_{0}$. From this equations we can find coefficients $c_{2}$ and $b_{2}$. The calculation of them is presented in [7].

From (2.9) we obtain, that

$$
\xi_{*}=\sqrt{\frac{\varepsilon}{b_{2}}}+O(\varepsilon), \text { then } \tau \approx \frac{1}{1+\frac{c_{2}}{b_{2}} \varepsilon}
$$

We get the periodical solution of system of differential equations $(2.6)-(2.7)$ :

$$
\left\{\begin{array}{l}
x(t)=\sqrt{\frac{\varepsilon}{b_{2}}} \cos \frac{\sigma_{0} t}{1+\frac{c_{2}}{b_{2}} \varepsilon}+O(\varepsilon), \\
y(t)=\sqrt{\frac{\varepsilon}{b_{2 *}}}\left(A_{s} \sin \frac{\sigma_{0} t}{1+\frac{c_{2}}{b_{2}} \varepsilon}+A_{c} \cos \frac{\sigma_{0} t}{1+\frac{c_{2}}{b_{2}} \varepsilon}\right)+O(\varepsilon) .
\end{array}\right.
$$

We solve the system of differential equations (2.1) and (2.2) by the RungeKutta method. Results of the computational experiment are presented in Fig.3 . 


\section{DYNAMIC OF DRILLING PROCESS}

The principle scheme of the drilling machine is presented in Fig. 4. There are two distinct oscillatory systems in drilling machine:

- Spindle with gear of the drive of rotation (oscillator $\varphi$ ),

- The whole spindle unit (oscillator $s$ ).

We shall show the origin of excitation, which takes place at drilling, assuming that drill is absolutely stiff. Change of magnitude of torque $M_{\varphi}$ is result of change of feed $s$ and speed of feed $s_{0}$ in drilling process. Analogical change of angular speed of drills $\varphi$ changes axial cutting force $P_{x}$. The possible reason of inhibition of oscillations is the delaying forces. The time of delay equal to the duration of rotation of the drill by $m$-th part of full angle ( $m$-cutting edges of the drill). In the case of deep drilling, one of run of elastic wave along the whole length of a drill plays the main role in inhibition oscillations.

In the case of non oscillating mode drilling, both axial components of cutting force $P_{x}$ and torque $M_{\varphi}$ are the functions of two independents variables, i.e. cutting speed $v_{0}=\Omega r$ (here $r$ is the radius of the drill) and speed of feed $s_{0}$. In this case the speed of feed $s_{0}$ is related to $v_{0}$ and $s_{0}$ by the following equation:

$$
s_{0}=s \Omega / 2 \pi .
$$

The increment of feed speed can vary independently to both the increment of cutting speed $v=\left.r \varphi\right|_{x=l}$ and feed $s$.

$$
\begin{aligned}
& P_{x}=P_{x}\left(s_{0}+\Delta s, v_{0}+v, s_{0}+s\right), \\
& M_{\varphi}=M_{\varphi}\left(s_{0}+\Delta s, v_{0}+v, s_{0}+s\right) .
\end{aligned}
$$

Here $\Delta s$-increment of thickness of the chip, $\varphi(x, t)_{x=l}$ - increment of angular speed of rotation of drill end. The thickness of the chip, cut by each edge at given moment of time, depending on trace on surface, formed by previous edge $h$ seconds earlier (Fig. 5), therefore

$$
\Delta s=m[s(t)-s(t-h)], \text { where } h=\left.\frac{2 \pi l}{m\left(v_{0}+v\right)}\right|_{x=l^{*}}
$$

In the case of vibrating mode of drilling, the increments of cutting forces in the dependence of $s_{0}, s_{0}, v_{0}$ are equal

$$
\begin{aligned}
& d P_{x}=k \Delta s+k s+k v(l, t), \\
& d M_{\varphi}=n \Delta s+n s+n v(l, t),
\end{aligned}
$$


where

$$
\begin{aligned}
& k_{1}=\left(\frac{\partial P_{x}}{\partial s}\right)_{0}, \quad k_{2}=\left(\frac{\partial P_{x}}{\partial s}\right)_{0}, \quad k_{3}=\left(\frac{\partial P_{x}}{\partial v}\right)_{0} \\
& n_{1}=\left(\frac{\partial M_{\varphi}}{\partial s}\right)_{0}, \quad n_{2}=\left(\frac{\partial M_{\varphi}}{\partial s}\right)_{0}, \quad n_{3}=\left(\frac{\partial M_{\varphi}}{\partial v}\right)_{0} .
\end{aligned}
$$

The equation of oscillation of oscillator $s$ at drilling is given by:

$$
M_{1} \ddot{s}+c_{1} \dot{s}+\lambda_{1} s=-d P_{x}
$$

where $M_{l}$ is the mass of the whole spindle unit of the machine tool, concentrated at $x=l ; c_{l}, \lambda_{l}$-coefficients of stiff and elasticity.

Let $\varphi(x, t)$ be an increment of an angle of a turn of cross section of the drill located on distance $x$ from the attachment point. Equation of rotation vibration of the drill is given by:

$$
\frac{\partial^{2} \varphi}{\partial t^{2}}=a \frac{\partial^{2} \varphi}{\partial x^{2}}+b \frac{\partial^{3} \varphi}{\partial x^{2} \partial t}
$$

where $a=G / \rho, b=\eta / \rho, \eta$ - coefficient of internal friction, $G$ - magnitude of shift, $\rho$ - density of the material.

The boundary condition is obtained assuming that the drill attached to the oscillator $\varphi$ stiffly. The oscillator $\varphi$ is characterized by the moment of inertia, with respect to the rotation axis $o o^{\prime}$, and coefficients $c_{2}, \lambda_{2}$. Thus we have the condition:

$$
\left.I \frac{\partial}{\partial x}\left(G \varphi-\frac{\partial \varphi}{\partial t}\right)\right|_{x=0}=\left.\left(I_{2} \frac{\partial^{2} \varphi}{\partial t^{2}}+c_{2} \frac{\partial \varphi}{\partial t}+\lambda_{2} \varphi\right)\right|_{x=0}
$$

where $I$ - polar moment of cross section of the drill. The second boundary condition at $x=l$ is obtained from equality of moments on the end of drill:

$$
\left.I \frac{\partial}{\partial x}\left(G \varphi-\frac{\partial \varphi}{\partial t}\right)\right|_{x=l}=-\left.d M_{\varphi}\right|_{x=l}
$$

Differencing equations (3.1), (3.2), (3.3) with respect to $t$ and substituting $\varphi=\frac{v}{r}$ we get the equation for $v$ :

$$
\frac{\partial^{2} v}{\partial t^{2}}=a \frac{\partial^{2} v}{\partial x^{2}}+b \frac{\partial^{3} v}{\partial x^{2} \partial t}
$$


with the boundary conditions:

$$
\begin{aligned}
& \left.\frac{I}{\lambda_{2}}\left(G \frac{\partial v}{\partial x}+\eta \frac{\partial v^{2}}{\partial x \partial t}\right)\right|_{x=0}=\left.\left(\frac{1}{\omega_{2}^{2}} \frac{\partial^{2} v}{\partial t^{2}}+\frac{c_{2}}{\lambda_{2}} \frac{\partial v}{\partial t}+v\right)\right|_{x=0} \\
& \frac{1}{\omega_{2}^{2}} \frac{\partial^{2} v}{\partial t^{2}}+\delta_{l} \frac{s v}{\partial t}+s+\frac{k_{l} m}{\lambda_{l}}\left[s(t)-s(t-h)+\frac{k_{3}}{\lambda_{l}} v(l, t)\right]=0 \\
& \left.\frac{I}{r}\left(G \frac{\partial v}{\partial x}+\eta \frac{\partial v^{2}}{\partial x \partial t}\right)\right|_{x=l} \\
& =\left.\frac{d}{d t}\left(n_{l}\left[s(t)-s(t-h)+n_{2} \frac{d s}{d t}+n_{3} v\right]\right)\right|_{x=l} .
\end{aligned}
$$

There $\omega_{1}$ and $\omega_{2}$ are frequencies of the oscillator $s$ and $\varphi(0, t), \delta_{l}=\left(c_{l}+\right.$ $\left.k_{2}\right) / \lambda_{1}, h=2 \pi r / v_{0}$. The linear analysis of model $(3.4)-(3.7)$ is conducted in [5].

We suppose, differently then it is stated in [5], that a particularity of plastic properties of metal is the cause of the self-excited oscillation in drilling process. Our future work is to make a linear and nonlinear analysis of differential equations of metal drilling process by the theory of bifurcation.

\section{CONCLUSIONS}

1. The delaying forces have influence on excitation of oscillation in metal cutting process and metal drilling process.

2. The system of differential equations has the stable periodical solution or asymptotically stable solution when the parameters have real values.

3 . Results of computational experiment of metal cutting process correspond with theoretical solution of system differential equation (2.1) - (2.2). When coefficients $\alpha_{1}, \alpha_{2}, \beta_{1}$ and $\beta_{2}$ have different values, we can find conditions, when the self-excited oscillations don't arise in metal cutting process.

\section{REFERENCES}

[1] D. De Bra. Vibration isolation of precision machine tools and instruments. CIRP, 41(2), $711-716,1992$

[2] M.E. Eljasberg. The theory and calculation of stability on metal cutting process. Stanki i Instrument, 11, 6 - 11, 1971. (in Russian)

[3] M.E. Eljasberg. About calcutalion of stability of metall cutting process. Stanki i Instrument, 2, $19-27,1975$. (in Russian)

[4] M.E. Eljasberg and M.G. Binder. Stability of oscillation system of metal cutting machine. Stanki i Instrument, 10, 19 - 22, 1989. (in Russian)

[5] J.N. Gorodeckij. The theory of excite of oscillation in metal drilling process. Radiofizika, 11(5), 776 - 786, 1969. (In Russian)

[6] J. Janutènienè and D. Švitra. Linear analysis of differecial equations of metal cutting process. LMD mokslo darbai, 2, $470-474,1998$. 
[7] J. Janutènienè and D. Švitra. Investigation of self-excited oscillation in metal cutting process. Mechanika, 26(6), $69-74,2000$.

[8] S. Ostholm. Simulering och Identifiering av skareggars mekaniska belastringsbild. Institutionen for mekanisk teknologi och verktysmaskiner Lunds tekniska horskola, 1991.

\section{Metalu pjovimo procesu tyrimas}

J. Janutėnienè, G. Pridotkas, R. Didžiokas

Straipsnyje nagrinėjami autosvyravimai atsirandantys metalų pjovimo bei metalų gręžimo procesuose. Pateiktos susižadinančių autosvyravimų dinamikos lygtys. Straipsnyje trumpai aprašytas metalų gręžimo procesas, užrašytos autosvyravimų dinamikos lygtys, suformuluotos kraštinès sąlygos. Autosvyravimu susižadinimo priežastis - vèluojančių jègu atsiradimas. Straipsnyje atlikta metalų pjovimo proceso metu susižadinančiu autosvyravimų dinamikos lygčių suvèlavimu, priklausančiu nuo ieškomos funkcijos, tiesinė analizè. Išskirta asimptotinio stabilumo sritis. Netiesine šiu lygčių analizė atlikta bifurkacijų teorijos metodu ir gauta asimptotinio sprendinio išraiška. Gautas sprendinys palygintas su skaitinio eksperimento rezultatais. 